\title{
UPAYA MENINGKATKAN MINAT MEMBACA SISWA MELALUI MODEL PEMBELAJARAN KOOPERATIF TIPE TARI BAMBU PADA KOMPETENSI DASAR MENANGGAPI ISI CERITA SECARA LISAN BIDANG STUDI BAHASA INDONESIA DI KELAS III SDN 060819 KEC. MEDAN KOTA
}

\author{
Ratna Dewi \\ Surel: ratnadewi02@yahoo.com
}

\begin{abstract}
ABSTRAK
Masalah yang dihadapi peneliti adalah masalah rendahnya minat belajar siswa pada mata pelajaran Bahasa Indonesia di Kelas III SD Negeri 060819 Kec.Medan Kota TA. Penelitian ini bertujuan untuk mengetahui apakah dengan menggunakan model pembelajaran kooperatif tipe tari bambu dapat meningkatkan minat belajar siswa pada mata pelajaran Bahasa Indonesia di Kelas III SD Negeri 060819 Kec.Medan Amplas Tahun Ajaran 2015/2016. Jenis penelitian ini adalah "Penelitian Tindakan Kelas", dengan menggunakan model pembelajaran kooperatif tipe tari bambu. Berdasarkan hasil observasi yang dilakukan penulis dengan guru Kelas III SD Negeri 060819 Kec. Medan Kota Tahun yang dilakukan terhadap 30 orang siswa terdapat 24 orang siswa (80\%) yang memiliki minat belajar yang kurang dan 6 orang siswa (20\%) yang memiliki minat yang cukup Berdasarkan hasil penelitian dari tes siklus I dengan siklus II terjadi peningkatan yang signifikan, pada siklus I memiliki nilai ratarata $44(55 \%)$, sedangkan pada siklus II yaitu sebesar 69 (87\%). Dengan demikian dapat disimpulkan model pembelajaran kooperatif tipe tari bambu dapat meningkatkan minat belajar siswa pada mata pelajaran Bahasa Indonesia pokok bahasan menanggapi isi cerita secara lisan di Kelas III SD Negeri 060819 Kec. Medan Kota Tahun Tahun Ajaran 2015/2016.
\end{abstract}

Kata Kunci: Minat Membaca, Model Pembelajaran Kooperatif Tipe Tari Bambu, Bahasa Indonesia

\section{PENDAHULUAN}

Pendidikan

merupakan

masalah yang sangat penting, karena pendidikan itu akan sangat berpengaruh terhadap perkembangan hidup manusia. Dengan semakin tingginya jenjang pendidikan yang ditempuh seseorang maka semakin besar pula kesempatan untuk meraih sukses hidup di masa mendatang. Secara garis besarnya, pendidikan sangat berkompeten dalam kehidupan, baik kehidupan diri sendiri, keluarga, masyarakat, maupun kehidupan bangsa dan negara.

Bahasa Indonesia merupakan salah satu mata pelajaran yang sangat penting sebagai sarana belajar bagi peserta didik. Bahasa Indonesia juga memiliki tujuan membekali peserta didik untuk mengembangkan bahasa di samping

SD Negeri 060819 Kec. Medan Kota 
aspek penalaran dan hafalan sehingga pengetahuan dan informasi yang diterima siswa tidak hanya sebatas bahasa dan sastra. Padahal dalam proses belajar mengajar keterlibatan siswa secara totalitas, artinya melibatkan pikiran, penglihatan, pendengaran dan psikomotor (keterampilan). Di samping pentingnya Bahasa Indonesia sebagai sarana belajar, peserta didik juga harus memiliki minat belajar yang besar, ketika kegiatan belajar mengajar dilaksanakan.

Minat adalah suatu rasa lebih suka dan rasa keterikatan pada suatu hal atau aktivitas, tanpa ada yang menyuruh. Minat pada dasarnya adalah penerimaan akan suatu hubungan antara diri sendiri dengan sesuatu di luar diri. Semakin kuat atau dekat hubungan tersebut, semakin besar minat. Suatu minat dapat diekspresikan melalui suatu pernyataan yang menunjukkan bahwa siswa lebih menyukai suatu hal daripada hal lainnya, dapat pula dimanifestasikan melalui partisipasi dalam suatu aktivitas. Minat tidak dibawa sejak lahir, melainkan diperoleh kemudian. Siswa yang memiliki minat terhadap subyek tertentu cenderung untuk memberikan perhatian yang lebih besar terhadap subyek tersebut.

Salah satu upaya yang dapat dilakukan untuk meningkatkan minat belajar siswa adalah dengan menggunakan model pembelajaran yang menarik bagi siswa. Yang dapat melatih keterampilan siswa baik keterampilan mendengar (listening), berbicara (speaking), membaca (reading) dan menulis (writing). Selain itu model pembelajaran yang menunjang aktifitas siswa belajar dengan model pembelajaran yang aktif dan tidak monoton akan membantu meningkatkan minat belajar siswa. Salah satunya adalah dengan menggunakan model pembelajaran kooperatif tipe tari bambu.

Teknik ini diberi nama Tari Bambu, karena siswa berjajar dan saling berhadapan dengan model yang mirip seperti dua potong bambu yang digunakan dalam Tari Bambu Filipina yang juga popular di beberapa daerah di Indonesia. Dalam kegiatan belajar mengajar dengan teknik ini, siswa saling berbagi informasi pada saat yang bersamaan. Pendekatan ini bisa digunakan dalam beberapa mata pelajaran, seperti ilmu pengetahuan sosial, agama, matematika, dan bahasa. Bahan pelajaran yang paling cocok digunakan dengan teknik ini adalah bahan yang membutuhkan pertukaran pengalaman, pikiran, dan informasi antarsiswa. Salah satu keunggulan teknik ini adalah adanya struktur yang jelas dan memungkinkan siswa untuk berbagi 
dengan pasangan yang berbeda dengan singkat dan teratur. Selain itu, siswa bekerja dengan sesama siswa dalam suasana gotong royong dan mempunyai banyak kesempatan untuk mengolah informasi dan meningkatkan keterampilan berkomunikasi. Tari bambu bisa digunakan untuk semua tingkatan usia anak didik.

Mengembangkan minat terhadap sesuatu pada dasarnya adalah membantu siswa melihat bagaimana hubungan antara materi yang diharapkan untuk dipelajarinya dengan dirinya sendiri sebagai individu. Proses ini berarti menunjukkan pada siswa bagaimana pegetahuan atau kecakapan tertentu mempengaruhi dirinya, melayani tujuan-tujuannya, memuaskan kebutuhan-kebutuhannya. Bila siswa menyadari bahwa belajar merupakan suatu alat untuk mencapai beberapa tujuan yang dianggapnya penting dan bila siswa melihat bahwa hasil dari pengalaman belajarnya akan membawa kemajuan pada dirinya, kemungkinan besar ia akan berminat (dan bermotivasi) untuk mempelajarinya. Di sana, mereka saling berkomunikasi secara lisan dengan lancar tanpa hambatan. Siswasiswa itu begitu mudah menuturkan isi hati mereka, ide, gagasan, dan pengalaman dengan mudah disampaikan dengan bahasa lisan. Ini menunjukkan bahwa siswa-siswa memiliki minat belajar yang cukup besar.

Model pembelajaran kooperatif tipe tari bambu merupakan model pembelajaran yang tepat dipilih dan dipergunakan untuk meningkatkan minat belajar siswa. Dalam metode ini siswa bermain seperti yang dialami dalam kehidupan mereka sehari-hari sehingga penerapan metode ini siswa lebih aktif dalam mengikuti pelajaran. Berdasarkan pemikiran di atas, maka peneliti tertarik untuk mengadakan judul "Upaya Meningkatkan Minat Membaca Siswa Melalui Model Pembelajaran Kooperatif Tipe Tari Bambu Pada Kompetensi Dasar Menanggapi Isi Cerita Secara Lisan Mata Pelajaran Bahasa Indonesia Di Kelas III SD Negeri 060819 Kec.Medan Kota T.A 2015/2016.

Sesuai dengan latar belakang dan fakta yang menyatakan bahwa kurangnya minat belajar siswa pada mata pelajaran Bahasa Indonesia disebabkan oleh beberapa faktor yaitu:

1. Guru kurang memotivasi dan memberi perhatian kepada siswa

2. Guru hanya menggunakan metode ceramah saja.

3. Guru jarang menggunakan media pada saat proses belajar mengajar. 
4. Siswa merasa takut untuk mengungkapkan pikiran dan idenya.

Tujuan dalam penelitian ini adalah: "Untuk mengetahui apakah model pembelajaran kooperatif tipe tari bambu dapat meningkatkan minat belajar siswa pada mata pelajaran Bahasa Indonesia pada materi pokok menanggapi isi cerita secara lisan di Kelas III SD Negeri 060819 Kec. Medan Kota Tahun Ajaran 2015/2016.'

Adapun manfaat yang ingin dicapai dari hasil penelitian ini adalah:

1. Sebagai bahan masukan agar siswa lebih kreatif lagi dalam menuangkan ide, gagasan serta pikirannya dalam berbicara.

2. Dapat memperoleh keterampilan baru yang dapat diterapkan dalam kegiatan pembelajaran yaitu dengan menggunakan model pembelajaran kooperatif sebagai sarana belajar dalam berinteraksi dengan teman dan melatih kemampuan berbicara siswa.

3. Dapat menerapkan model pembelajaran yang baru pada saat kegiatan belajar mengajar di sekolah tersebut, dimana siswanya akan menjadi lebih aktif serta dapat meningkatkan minat belajar siswa.

4. Sebagai bahan usul kenaikan pangkat satu tingkat.
METODE PENELITIAN

Dalam penelitian ini penulis menggunakan jenis penelitian tindakan kelas (PTK) yang bertujuan untuk memperbaiki proses pembelajaran dalam meningkatkan minat belajar Bahasa Indonesia siswa dengan menggunakan model pembelajaran kooperatif tipe Tari Bambu.

Subjek dalam penelitian ini adalah seluruh siswa Kelas III SD Negeri 060819 Kec.Medan Kota Tahun Ajaran 2015/2016. Objek penelitian ini adalah peningkatan minat belajar melalui penggunaan model pembelajaran kooperatif tipe tari bambu pada mata pelajaran Bahasa Indonesia siswa Kelas III SD Negeri 060819 Kec. Medan Kota yang berjumlah 30 orang.

Penelitian ini menggunakan desain model Kemmis dan taggart dalam Arikunto (2006:16). Menurut Arikunto mengemukan secara garis besar terdapat empat tahapan yang dilalui dalam melaksanakan penelitian tindakan kelas di mana masingmasing siklus terdiri dari empat langkah, yaitu (1) perencanaan (planning), (2) pelaksanaan (acting), (3) pengamatan (observing), dan (4) refleksi (reflecting). Adapun model dan penjelasan untuk masing-masing tahap adalah seperti disajikan pada gambar di bawah ini: 


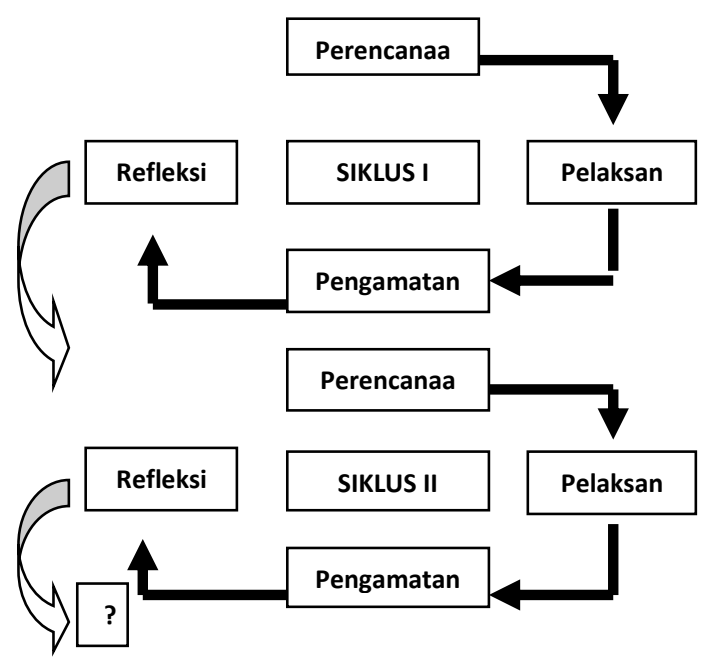

Gambar 3.1. Skema Pelaksanaan Tindakan Kelas (PTK)

Sesuai dengan jenis penelitian ini, yaitu penelitian tindakan kelas, maka penelitian ini memiliki beberapa tahap yang merupakan suatu siklus. Tiap siklus dilaksanakan sesuai dengan perubahan yang dicapai. Pada penelitian ini akan dilaksnakan dua siklus, yaitu: Siklus I dilaksanakan dengan menggunakan Tes awal. Tes awal diberikan untuk mengetahui bagaimana minat belajar siswa dalam menanggapi isi cerita secara lisan. Sebelum pelaksanaan siklus I siswa diberi tes terlebih dahulu, untuk mengetahui letak kesulitan masing-masing siswa. Selain itu, pada siklus I dilakukan juga observasi dan evaluasi terhadap siswa. Dari observasi dan evaluasi maka dilakukan refleksi tehadap pemberian tindakan pada siklus I yang dijadikan sebagai pedoman pelaksanaan siklus I.

Apabila pada siklus I minat belajar siswa dalam menanggapi isi cerita secara lisan belum menujukkan ketuntasan maka dilanjutkan dengan siklus berikutnya. Adapun prosedur dilaksankan sebagai berikut: (1) perencanaan, (2) pelaksanaan, (3) observasi, (4) refleksi, yang dilaksnakan dalam setiap siklus.

Secara rinci prosedur penelitian tindakan kelas untuk siklus I dapat dijabarkan sebagai berikut:

\section{Siklus I}

Sebelum melakukan kegiatan guru melakukan persiapan demi kelancaran pelaksanaan penelitian tindakan kelas ini. Permasalahan yang diidentifikasi pada pembelajaran bahasa Indonesia yang terkait dengan meningkatkan minat belajar pada siswa SD Negeri 060819 Kec. Medan Kota, diusahakan pemecahan dengan menerapkan model pembelajaran kooperatif tipe tari bambu. Sesuai dengan metode pembelajaran yang dipilih, maka perencaan-perencaan oleh guru bersama guru dilakukan pada tahap seperti berikut ini yaitu:

a. Menyusun persiapan mengajar rencana pelaksaan pembelajaran (RPP) sesuai dengan pokok bahasan yang akan diajarkan pada setiap pertemuan 
b. Memberi penjelasan dan melatih guru mengenai penerapan model pembelajaran kooperatif tipe Tari Bambu

c. Menyiapkan gambar-gambar yang akan dibagikan kepada siswa sebagai bahan pelajaran bagi siwa dalam menanggapi isi cerita secara lisan untuk mengetahui tingkat keberhasilan yang dicapai siswa dengan diterapkannya model pembelajaran kooperatif tipe Tari Bambu

d. Menyiapkan sumber belajar berupa buku pelajaran Bahasa Indonesia kelas III

e. Membuat lembar observasi guna mengamati proses pembelajaran

Dalam pelaksanaan PTK,
istilah dipahami aktivitas yang
dirancang dengan sistematis untuk
menghasilkan adanya peningkatan
atau perbaikan dalam proses
pembelajaran. Dalam melaksanakan
tindakan maka perlu menyusun
langkah-langkah oprasional atau
skenario pembelajaran dari tindakan
yang dilakukan dengan
memperlihatkan tindakan yang ingin
diterapkan yaitu model pembelajaran
kooperatif tipe tari bambu. Pelakasaan
tindakannya yaitu:

a. Pendahuluan

1) Guru mengucapkan salam pembuka
2) Guru membuka pelajaran dengan cara mengabsensi kehadiran siswa

3) Guru melakukan apersepsi terhadap materi yang akan disampaikan dengan mengadakan motivasi kepada siswa

4) Guru menyampaikan tujuan pembelajaran

b. Kegiatan Inti

1) Guru menjelaskan materi pelajaran yaitu menanggapi isi cerita secara lisan

2) Guru memberikan sebuah gambar

3) Guru menjelaskan aturanaturan dalam menanggapi isi cerita secara lisan tersebut

4) Guru memberikan petunjuk kepada siswa tentang isi gambar

5) Siswa diberi waktu untuk memahami isi gambar tersebut

6) Siswa diberi waktu untuk menanggapi isi cerita secara lisan tersebut dengan katakatanya sendiri tanpa ada bantuan dari temannya

7) Peneliti membagi siswa menjadi 3 kelompok yang terdiri dari 5 pasang tiap kelompoknya

8) Guru menyuruh siswa untuk duduk berjajar di kursi yang telah disusun sebelumnya 
sesuai dengan kelompoknya masing - masing

9) Guru dan peneliti memonitor jalannya model pembelajaran kooperatif tipe tari bambu

10) Guru melaksanakan tes tertulis dan lisan.

c. Penutup

1) Guru memberi masukan tentang model pembelajaran kooperatif tipe Tari Bambu yang dilakukan oleh siswa.

Kegiatan yang dilakukan pada tahap pengamatan adalah:

a. Observasi dilaksanakan untuk mengamati proses pembelajaran di kelas secara langsung dengan dibantu guru kelas. Kegiatan yang diamati meliputi aktivitas guru dan anak didik dalam proses pembelajaran. Observasi ini berguna mnegetahui sejauh mana pelaksanaan tindakan dapat menghasilkan perubahan sesuai dengan yang dikehendaki.

b. Melaksanakan evaluasi untuk mengukur hasil belajar siswa sesudah diterapkan tindakan. Evaluasi ini dilakukan dengan menggunakan tes hasil belajar Bahasa Indonesia.

Selanjutnya refleksi dilakukan berdasarkan hasil analisa data observasi di dalam kelas dan tes hasil belajar siswa. Refleksi ini dilakukan mengarahkan kepada perbaikanperbaikan tindakan selanjutnya. Refleksi ini dilakukan untuk menganalisa perbaikan makna terhadap kesimpulan dari tindakan perbaikan yang telah dilakukan. Hasil refleksi ini kemudian digunakan sebagai dasar untuk tahap perencanaan pada siklus selanjutnya.

Setelah siklus I dilakukan dan sebelum menunjukkan hasil pada kemampuan siswa dalam meningkatkan minat belajar siswa dalam menanggapi isi cerita secara lisan. Maka dalam hal ini dilaksanakan sikulus II dengan tahapan yang sama sebagai berikut:

Siklus II

Pada siklus I direncanakan melaksanakan kembali program siklus II dengan terlebih dahulu mengidentifikasi kelemahankelemahan yang terdapat pada siswa di siklus I. Adapun rencana kegiatan pada tahap ini adalah:

a. Mengidentifikasi kelemahan pembelajaran selama sikulus I

b. Menyusun persiapan mengajar rencana pelaksaan pembelajaran (RPP) sesuai dengan pokok bahasan yang akan diajarkan pada setiap pertemuan

c. Memberi penjelasan dan melatih guru mengenai penerapan model 
pembelajaran kooperatif tipe tari bambu

d. Mengadakan media bantu yang dibutuhkan berupa gambar

e. Menyuruh siswa untuk menanggapi isi cerita secara lisan dengan menggunakan katakatanya sendiri berdasarkan media gambar yang telah di berikan

f. Menyusun siswa untuk berjajar berkelompok seperti pada kegiatan inti siklus I, untuk mengetahui tingkat keberhasilan yang dicapai siswa dengan diterapkannya model pembelajaran kooperatif tipe tari bambu

g. Menyiapkan sumber belajar berupa buku pelajaran Bahasa Indonesia kelas V

h. Membuat lembar observasi guna mengamati proses pembelajaran

$\begin{array}{rcr}\text { Pada } & \text { tahap } & \text { kegiatan } \\ \text { pelaksanaan, } & \text { kegiatan } & \text { yang }\end{array}$ dilaksanakan adalah sama seperti pada siklus I yaitu dengan menggunakan model pembelajaran kooperatif tipe tari bambu juga, yaitu:

a. Guru mengarahkan siswa untuk lebih berani dalam berinteraksi dengan teman yang lain, bertukar informasi, menanggapi isi cerita secara lisan dengan kata-kata sendiri dengan susunan kata- kata yang baik dan tepat b. Guru memberikan motivasi dan penguatan agar siswa tidak merasa takut dan percaya diri untuk kedepan kelas pada saat memulai kegiatan belajar mengajar dengan menggunakan model pembelajaran tipe tari bambu

c. Sebelum masuk ke materi guru terlebih dahulu memberikan petunjuk kepada siswa tentang tata cara bertukar informasi dengan menggunakan model pembelajaran kooperatif tipe tari bambu

d. Guru membagi kelompok dengan berjajar seperti pada siklus I

e. Guru memberikan masukan tentang pembelajaran yang telah dilakukan siswa dengan menggunakan model pembelajaran tipe Tari Bambu

f. Melaksanakan kegiatan sesuai dengan skenario pembelajaran atau Rencana Pelaksanaan Pembelajaran (RPP)

Seperti pada siklus I, pengamatan dilakukan untuk melihat perubahan-perubahan yang terjadi pada siswa dengan adanya penggunaan model pembelajaran kooperatif tipe tari bambu. Kemudian pada siklus II ini dilakukan untuk mengetahui minat belajar siswa terhadap materi menanggapi isi cerita secara lisan dengan kata-kata sendiri, 
dengan menggunakan model pembelajaran kooperatif tipe tari bambu dengan media gambar. Guru sebagai observer mengamati kegiatan selama proses pembelajaran berlangsung dengan berpedoman pada lembar observasi, dan pengamatan ini diperjelas dengan pengambilan foto dan video. Hasil obervasi ini ditindak lanjuti analisis untuk bahan refleksi.

Refleksi dilakukan pada akhir siklus II. Kegiatan ini dilakukan untuk melihat hasil perkembangan pelaksaan dan membuat kesimpulan mengenai kekurangan dan kelebihan yang telah dilakukan.

Pengumpulan data sesuai dengan tujuan penelitian ini, maka pengumpulan data diperoleh melalui observasi yang dilakukan oleh guru bersama guru Kelas III SD Negeri 060819 Kec. Medan Kota, dokumentasi meningkatkan minat belajar siswa dalam pokok bahasan menanggapi isi cerita secara lisan. Pengelolaan data yang dilakukan, mempergunakan model pembelajaran tipe tari bambu. Pengumpulan data dalam peneltitian ini dilakukan melalui observasi.

Observasi dilakukan untuk mengamati seluruh kegiatan dan perubahan yang terjadi saat dilakukannya tindakan. Observasi yang dilakukan berupa pengamatan terhadap seluruh kegiatan proses belajar mengajar melalui metode simulasi bertujuan untuk mengetahui perubahan yang terjadi saat dilakukan tindakan. Lembar observasi terhadap kelas selama berlangsung kegiatan pembelajaran sebagai berikut:

a. Aktivitas pembelajaran yang dilakukan guru/peneliti

b. Aktivitas siswa selama berlangsung pembelajaran

Instrumen penelitian ini menggunakan observasi berupa pertanyaan observasi yang digunakan untuk mengumpulkan data.

Teknik analisis dilakukan dengan dua cara, yaitu secara klasikal dan individu.

1. Klasikal

Analisis ini digunakan untuk mengetahui berhasil atau tidaknya tindakan yang dilakukan dengan menggunakan rumus untuk variabel minat, menurut Rosmala Dewi (2009:114) adalah sebagai berikut:

$$
P=\frac{F}{N} x 100 \%
$$

Keterangan:

$\mathrm{P}=$ Angka minat

$\mathrm{F}=$ Jumlah siswa yang mengalami perubahan

$\mathrm{N}=$ Jumlah seluruh siswa

2. Individu

Untuk menghitung data individu, menurut Muslich (2011:161), maka digunakan rumus: 
$=\frac{\text { Nilai rata }- \text { rata indikator yang dilaksanakan }}{\text { Indikator yang ada }} \times 100 \%$

Kriteria untuk menentukan keberhasilan tindakan dalam minat belajar siswa sebagai berikut:

1. Sangat berminat: $86 \%-100 \%$, dari jumlah siswa tiap indikator.

2. Berminat: $71 \%-85 \%$, dari jumlah siswa tiap indikator.

3. Cukup berminat: $60 \%-70 \%$, dari jumlah siswa tiap indikator.

4. Kurang berminat: $<60 \%$, dari jumlah siswa tiap indikator.

Penelitian ini dilaksanakan di SD Negeri 060819 Kec. Medan Kota Tahun Ajaran 2015/2016 dan waktu penelitian selama 3 (tiga) bulan.

\section{HASIL DAN PEMBAHASAN}

Pada tahap perencanaan di siklus I guru mempersiapkan siklus I dengan beberapa kegiatan dalam pembelajaran dan instrumen penelitian siswa dengan menerapkan pembelajaran yang menggunakan model pembelajaran kooperatif tipe tari bambu dengan membagi siswa dalam kelompok belajar.

$$
\text { Langkah-langkah yang }
$$

disusun dalam RPP dengan menggunakan model pembelajaran kooperatif tipe tari bambu, dimana model pembelajaran ini akan mengaktifkan siswa untuk mempelajari dan mengerjakan latihan baik secara individu maupun berkelompok. Sedangkan instrumen penelitian adalah lembar observasi. Pada siklus ini dilakukan 2 kali pertemuan, pertemuan berlangsung selama 4 jam pelajaran (4 $\quad$ x 35 menit).

Pada kegiatan ini peneliti menerapkan penggunaan model pembelajaran kooperatif tipe tari bambu yang bertujuan untuk meningkatkan minat belajar siswa pada mata pelajaran Bahasa Indonesia pokok bahasan menanggapi isi cerita secara lisan, dengan alokasi waktu $2 \mathrm{x}$ 35 menit (kegiatan awal 10 menit, kegiatan inti 50 menit, dan kegiatan akhir 10 menit).

Kegiatan yang dilakukan untuk peningkatan minat belajar siswa adalah membagi peserta didik menjadi beberapa kelompok secara heterogen agar merata antara kemampuan masing-masing peserta didik, memberikan informasi kepada siswa bagaimana prosedur model pembelajaran kooperatif tipe tari bambu, menjelaskan materi pelajaran yaitu menanggapi isi cerita secara lisan berdasarkan gambar dengan kalimatnya sendiri, dengan jelas dan singkat. Selanjutnya peneliti meminta peserta didik untuk melakukan pemahaman tentanng materi menanggapi isi cerita secara lisan berdasarkan gambar dengan 
kalimatnya sendiri, kemudian guru membimbing peserta didik selama proses belajar mengajar. Setelah peserta didik menyelesaikan tugasnya untuk menanggapi isi cerita secara lisan berdasarkan gambar dengan waktu yang telah ditentukan oleh guru, kemudian peserta didik didorong untuk saling bertukar informasi tentang hasil tulisannya kepada teman yang berada di hadapannya berdasarkan kelompok yang telah disusun dengan waktu yang telah ditentukan oleh guru.

Selanjutnya guru memberikan kesempatan kepada peserta didik untuk bertanya tentang hal-hal yang kurang dimengerti peserta didik pada materi pelajaran menanggapi isi cerita secara lisan berdasarkan gambar, serta menjelaskan kembali secara singkat, peneliti bertanya jawab dengan peserta didik tentang seputar materi pelajaran menanggapi isi cerita secara lisan berdasarkan gambar dan bersama-sama dengan peserta didik membuat kesimpulan.

Pada tahap pengamatan, peneliti bersama guru kelas melakukan observasi guru dan observasi siswa dengan menggunakan alat bantu check list terhadap pelaksanaan kegiatan pembelajaran berlangsung yang menggunakan metode pemberian tugas. Pada saat pembelajaran berlangsung, obsever melakukan observasi terhadap peneliti, obsever dan peneliti melakuakan observasi perilaku belajar siswa terhadap minat belajar siswa. Setelah pelaksanaan siklus I berakhir, guru memberikan evaluasi belajar untuk menambah penguatan dalam dalam mengetahui minta belajar siswa dan keberhasilan metode pemberian tugas yangn digunakan.

Selama pengamatan, banyak hal yang diperoleh antara lain: 1) siswa belum dapat berinteraksi dengan peneliti maupun berinteraksi dengan teman-teman sekelas, 2) pada kegiatan ini, ada beberapa siswa yang masih enggan untuk mengemukakan pendapatnya, 3) pada kegiatan ini, masih ditemukan siswa yang lebih mementingkan bermain daripada langsung mengerjakan tugas yang diberikan, sehingga mereka tidak dapat menyelesaikan tugas yang diberikan dengan tepat waktu, 4) peneliti kurang menguasai kelas, 5) ada beberapa siswa yang sama sekali tidak mengerjakan tugas yang diberikan oleh guru, 6) siswa belum aktif dalam menyelesaikan tugas yang telah diberikan.

$$
\begin{gathered}
\mathrm{P}=\frac{\text { Nilai Rata-Rata Indikator Yang Dilaksanakan }}{\text { Indikator Yang Ada }} \times 100 \% \\
\mathrm{P}=\frac{46}{80} \times 100 \% \\
\mathrm{P}=58 \%
\end{gathered}
$$

Dai hasil observasi pada siklus I di atas menunjukkan bahwa kompetensi peneliti masih kurang, 
sehingga perlu dilakukan inovasi lebih lanjut agar pembelajaran mencapai tujuan seperti yang

a. Guru melakukan appersepsi hanya mendapat nilai 3

b. Guru memotivasi seluruh siswa hanya mendapat nilai 1

c. Guru menjelaskan pokok bahasan menanggapi isi cerita secara lisan mendapat nilai 3

d. Guru menjelaskan dengan cara yang mudah dimengerti oleh siswa mendapat nilai 2

e. Guru menjelaskan materi dengan tidak bertele-tele mendapat nilai 2

f. Guru dapat memberi contoh menanggapi isi cerita secara lisan mendapat nilai 3

g. Guru menjelaskan manfaat menanggapi isi cerita secara lisan mendapat nilai 2

h. Guru memberi kesempatan kepada siswa untuk bertanya dan mampu menjawab pertanyaan dari siswa hanya mendapat nilai 2

i. Guru menjelaskan tugas kepada siswa mendapat nilai 3

j. Guru membagikan siswa dalam kelompok dan memberikan tugas mendapat nilai 3

k. Guru berkeliling mengawasi kegiatan selama kerja kelompok itu berlangsung, bila perlu memberi saran/pertanyaan mendapat nilai 3 diharapkan. Adapun penjelasannya adalah:

1. Guru menyuruh siswa untuk saling bekerjasama dalam tugas kelompok masing-masing mendapat nilai 2

m. Guru mengingatkan siswa untuk menyelesaikan tugas kelompok tepat pada waktunya hanya mendapat nilai 3

n. Guru memberikan skor kepada masing-masing kelompok masing -masing mendapat nilai 2

o. Guru menyuruh siswa membacakan hasil diskusi kelompok di depan kelas hanya mendapat nilai 1

p. Guru menyimpulkan dan merangkum hasil kerja kelompok mendapat nilai 3

q. Guru bertanya kepada siswa tentang materi yang kurang jelas mendapat nilai 2

r. Guru menyuruh siswa mencatat kesimpulan dari hasil kerja kelompok mendapat nilai 2

s. Guru merangkum bersama-sama hasil dari pelajaran mendapat nilai 2

t. Guru memberikan tugas kepada siswa / PR mendapat nilai 2

Jumlah siswa yang aktif dan berminat dirangkum pada Tabel berikut ini: 
Tabel 4.3. Siswa yang Aktif Selama Siklus I

\begin{tabular}{|c|c|c|c|}
\hline Keaktifan & $\mathrm{F}$ & $\%$ & Keterangan \\
\hline $\begin{array}{l}86 \%- \\
100 \%\end{array}$ & 0 & 0 & $\begin{array}{c}\text { Sangat } \\
\text { Berminat }\end{array}$ \\
\hline $\begin{array}{l}71 \%- \\
85 \%\end{array}$ & 1 & 3 & Berminat \\
\hline $\begin{array}{l}60 \%- \\
70 \%\end{array}$ & 5 & 17 & $\begin{array}{c}\text { Cukup } \\
\text { Berminat }\end{array}$ \\
\hline$<60 \%$ & 24 & 80 & $\begin{array}{c}\text { Kurang } \\
\text { Berminat }\end{array}$ \\
\hline Jumlah & 30 & 100 & - \\
\hline
\end{tabular}

Berdasarkan Tabel 4.3 di atas dapat dinyatakan bahwa hasil observasi siklus I yang dilakukan oleh guru dari 30 jumlah siswa, yakni diperoleh nilai sebagai berikut:

a. Siswa yang berminat sebanyak 1 orang dengan persentase $3 \%$.

b. Siswa yang cukup berminat sebanyak 5 orang dengan persentase $17 \%$.

c. Siswa yang kurang berminat sebanyak 24 orang dengan persentase $80 \%$.

3. Hasil observasi minat belajar siswa secara keseluruhan

Data dari hasil observasi siswa pada siklus I dapat diketahui bahwa minat belajar siswa Kelas III SD Negeri 060819 Kec. Medan Kota, dapat dikatakan masih kurang. Hal ini dapat dilihat dari data observasi siswa yang berdasarkan dari indikator minat, yaitu:

a. Observasi siswa mengenai minat mengikuti pelajaran terdiri dari 4 deskriptor, yaitu siswa memperhatikan guru mengajar sebanyak 19 siswa (63\%), siswa tidak ribut pada saat pembelajaran berlangsung sebanyak 16 siswa (53\%), siswa menulis pelajaran yang disampaikan guru sebanyak 13 siswa (43\%), siswa mampu mempraktekkan pelajaran sesuai dengan permintaan guru sebanyak 9 siswa (30\%).

b. Observasi siswa mengenai minat pemanfaatan waktu belajar terdiri dari 4 deskriptor, yaitu siswa menyusun kegiatan belajar sehari-hari sebanyak 6 siswa (20\%), siswa tidak suka berlama -lama di luar kelas pada saat istirahat sudah berakhir sebanyak 10 siswa (33\%), siswa memanfaatkan waktu istirahat untuk mendiskusikan pelajaran dengan temannya sebanyak 4 siswa (13\%), siswa tidak suka bermain sebelum tugasnya selesai sebanyak 7 siswa (23\%).

c. Observasi siswa mengenai minat mengulang pelajaran kembali terdiri dari 4 deskriptor, yaitu siswa membaca buku pelajaran setelah pelajaran berakhir sebanyak 3 siswa (10\%), siswa membuat ringkasan setelah pelajaran berakhir sebanyak 5 siswa (17\%), siswa mengingat apa yang sudah dipelajari 
sebanyak 12 siswa (40\%), siswa mengerjakan PR sebanyak 21 siswa (70\%).

Observasi siswa mengenai minat menyenangi pelajaran terdiri dari 4 deskriptor, yaitu siswa cepat datang ke sekolah sebanyak 23 siswa (77\%), siswa menyediakan perlengkapan untuk belajar sebanyak 13 siswa (43\%), siswa memberi tanda pada hal - hal yang penting sebanyak 4 siswa (13\%), siswa selalu bersemangat pada saat mengikuti pembelajaran sebanyak 8 siswa (27\%). Observasi siswa mengenai minat aktif di dalam kelas terdiri dari 4 deskriptor, yaitu siswa selalu menulis dan mencatat pelajaran penting sebanyak 6 siswa (20\%), siswa sering bertanya sebanyak 4 siswa (13\%), siswa sering menjawab pertanyaan sebanyak 4 siswa (13\%), siswa selalu mengeluarkan pendapat dalam diskusi kelompok sebanyak 7 siswa $(23 \%)$.

Dari hasil observasi siklus I pada tabel di atas masih tergolong kurang. Oleh karena itu peneliti melanjutkan kegiatan ini ke siklus II agar indikator-indikator observasi siswa dapat mencapai taraf persentase yang tinggi. Hasil observasi siklus I yang dilakukan oleh guru dari 30 jumlah siswa, yakni diperoleh nilai sebagai berikut: Siswa yang kurang berminat sebanyak 24 orang dengan persentase $80 \%$.

Dari hasil observasi siswa yang telah dilakukan pada siklus I, maka guru melakukan refleksi pada siklus I yang hasilnya adalah: 1) peneliti kurang menguasai kelas dengan baik, 2) siswa belum aktif dalam menjawab/menyelesaikan tugas yang diberikan peneliti, karena peneliti kurang menguasai model pembelajaran, 2) di dalam proses pembelajaran, guru belum dapat menggunakan waktu yang efektif sehingga tujuan pembelajaran belum tercapai, 3) aktivitas guru dalam bertanya kepada siswa, memperhatikan dan membimbing siswa harus lebih ditingkatkan lagi, 4) tahap kegiatan akhir, peneliti diharapkan dapat melaksanakan penilaian pembelajaran dan lebih sempurna lagi dalam merangkum isi pelajaran, 5) lebih memfokuskan menyelesaikan tugas siswa dalam menyelesaikan susunan cerita melalui gambar, serta saling berinteraksi mengeluarkan pendapat tentang gambar yang dilihatnya dengan teman dalam kelompoknya. 
Tahap perencanaan pada siklus II merupakan hasil refleksi dari siklus I dimana hasil pada siklus I belum mencapai tujuan yang telah ditetapkan. Pada tahap siklus II ini peneliti membuat perencanaan tindakan untuk meningkatkan kemampuan siswa dalam menyelesaikan soal.

Langkah-langkah yang
disusun dalam RPP dengan menggunakan model pembelajaran kooperatif tipe tari bambu, dimana model pembelajaran ini akan mengaktifkan siswa untuk mempelajari dan mengerjakan latihan baik secara individu maupun berkelompok. Sedangkan instrumen penelitian adalah lembar observasi. Pada siklus ini dilakukan 2 kali pertemuan, pertemuan berlangsung selama 4 jam pelajaran (4x35 menit).

Pada kegiatan ini guru menerapkan penggunaan model pembelajaran kooperatif tipe tari bambu yang bertujuan untuk meningkatkan minat belajar siswa pada mata pelajaran Bahasa Indonesia pokok bahasan menanggapi isi cerita secara lisan, dengan alokasi waktu $2 \mathrm{x}$ 35 menit (kegiatan awal 10 menit, kegiatan inti 50 menit, dan kegiatan akhir 10 menit).

Setelah peserta didik menyelesaikan tugasnya untuk menanggapi isi cerita secara lisan berdasarkan gambar dengan waktu yang telah ditentukan oleh guru, kemudian peserta didik didorong untuk saling bertukar informasi tentang hasil tulisannya kepada teman yang berada di hadapannya berdasarkan kelompok yang telah disusun dengan waktu yang telah ditentukan oleh guru. Selanjutnya guru memberikan kesempatan kepada peserta didik untuk bertanya tentang hal-hal yang kurang dimengerti peserta didik pada materi pelajaran menanggapi isi cerita secara lisan berdasarkan gambar, serta menjelaskan kembali secara singkat, peneliti bertanya-jawab dengan peserta didik tentang seputar materi pelajaran menanggapi isi cerita secara lisan berdasarkan gambar dan bersama-sama dengan peserta didik membuat kesimpulan.

$$
\text { Pada tahap ini, peneliti }
$$
bersama guru kelas melakukan observasi guru dan observasi siswa dengan menggunakan alat bantu check list terhadap pelaksanaan kegiatan pembelajaran berlangsung yang menggunakan metode pemberian tugas. Pada saat pembelajaran berlangsung, obsever melakukan observasi terhadap peneliti, obsever dan guru melakukan observasi perilaku belajar siswa terhadap minat belajar siswa. Setelah pelaksanaan siklus II berakhir, guru memberikan evaluasi belajar untuk menambah penguatan dalam dalam 
mengetahui minta belajar siswa dan keberhasilan metode pemberian tugas yang digunakan.

Selama observasi banyak hal yang diperoleh antara lain: 1) siswa cepat berinteraksi dengan peneliti maupun berinteraksi dengan temanteman sekelas, 2) pada tahap ini siswa tidak enggan lagi untuk mengemukakan pendapatnya, 3) siswa selalu mengikuti kegiatan pembelajaran dengan penuh semangat tinggi dan tidak cepat putus asa dalam mengerjakan tugas yang diberikan oleh guru, 4) peneliti sudah dapat menguasai kelas dengan baik, 5) pada kegiatan ini siswa sudah langsung mengerjakan tugas yang diberikan, sehingga mereka telah bertanggung jawab dengan tugas yang deiberikan, 6) siswa sudah aktif dalam menanggapi isi cerita secara lisan melalui gambar yang ditunjukkan kepadanya.

Berdasarkan hasil observasi
yang dilakukan peneliti, maka
diperoleh sebagai berikut:

1. Hasil observasi kegiatan guru

Untuk mengetahui berapa persen (\%) hasil observasi peneliti digunakan rumus sebagai berikut:

$$
\begin{gathered}
\mathrm{P}=\frac{\text { Nilai Rata }- \text { Rata Indikator Yang Dilaksanakan }}{\text { Indikator Yang Ada }} \times 100 \% \\
\mathrm{P}=\frac{72}{80} \times 100 \% \\
\mathrm{P}=90 \%
\end{gathered}
$$

Hasil di atas menunjukkan bahwa kompetensi guru telah mengalami perubahan dan mencapai taraf persentase yang lebih tinggi, namun masih terdapat beberapa yang masih memiliki nilai rendah, sehingga perlu dilakukan inovasi lebih lanjut agar pembelajaran mencapai tujuan seperti yang diharapkan. Adapun penjelasannya sebagai berikut:

a. Guru melakukan appersepsi hanya mendapat nilai 4

b. Guru memotivasi seluruh siswa hanya mendapat nilai 4

c. Guru menjelaskan pokok bahasan menanggapi isi cerita secara lisan mendapat nilai 4

d. Guru menjelaskan dengan cara yang mudah dimengerti oleh siswa mendapat nilai 3

e. Guru menjelaskan materi dengan tidak bertele - tele mendapat nilai 3

f. Guru dapat memberi contoh menanggapi isi cerita secara lisan mendapat nilai 4

g. Guru menjelaskan manfaat menanggapi isi cerita secara lisan mendapat nilai 4

h. Guru memberi kesempatan kepada siswa untuk bertanya dan mampu menjawab pertanyaan dari siswa hanya mendapat nilai 4

i. Guru menjelaskan tugas kepada siswa mendapat nilai 4 
j. Guru membagikan siswa dalam kelompok dan memberikan tugas mendapat nilai 3

k. Guru berkeliling mengawasi kegiatan selama kerja kelompok itu berlangsung, bila perlu memberi saran/pertanyaan mendapat nilai 4

1. Guru menyuruh siswa untuk saling bekerjasama dalam tugas kelompok masing-masing mendapat nilai 4

m. Guru mengingatkan siswa untuk menyelesaikan tugas kelompok tepat pada waktunya hanya mendapat nilai 3

n. Guru memberikan skor kepada masing-masing kelompok masing - masing mendapat nilai 3

o. Guru menyuruh siswa membacakan hasil diskusi kelompok di depan kelas hanya mendapat nilai 3

p. Guru menyimpulkan dan merangkum hasil kerja kelompok mendapat nilai 3

q. Guru bertanya kepada siswa tentang materi yang kurang jelas mendapat nilai 4

r. Guru menyuruh siswa mencatat kesimpulan dari hasil kerja kelompok mendapat nilai 3

s. Guru merangkum bersama - sama hasil dari pelajaran mendapat nilai 4

t. Guru memberikan tugas kepada siswa / PR mendapat nilai 4.
Pada siklus II observasi peneliti telah mengalami perubahan dan mencapai taraf persentase yang tinggi. Hal ini dapat dilihat dari nilai keseluruhan yang diperoleh sebesar 72 , (\%) atau persen yang diperoleh sebesar $90 \%$.

2. Hasil observasi minat siswa secara individu

Jumlah siswa yang aktif dan berminat dirangkum pada tabel berikut ini:

Tabel 4.7 Siswa yang Aktif Selama Siklus II

\begin{tabular}{|c|c|c|c|}
\hline Keaktifan & $\mathrm{F}$ & $\%$ & Keterangan \\
\hline $\begin{array}{c}86 \%- \\
100 \%\end{array}$ & 20 & 67 & $\begin{array}{c}\text { Sangat } \\
\text { Berminat }\end{array}$ \\
\hline $71 \%-85 \%$ & 10 & 33 & Berminat \\
\hline $60 \%-70 \%$ & - & - & $\begin{array}{c}\text { Cukup } \\
\text { Berminat }\end{array}$ \\
\hline$<60 \%$ & - & - & $\begin{array}{c}\text { Kurang } \\
\text { Berminat }\end{array}$ \\
\hline Jumlah & 30 & 100 & - \\
\hline
\end{tabular}

Berdasarkan tabel 4.3 di atas dapat dinyatakan bahwa hasil observasi siklus II yang dilakukan oleh guru dari 30 jumlah siswa, yakni diperoleh nilai sebagai berikut:

a. Siswa yang sangat berminat sebanyak 20 orang dengan persentase $67 \%$.

b. Siswa yang berminat sebanyak 10 orang dengan persentase $33 \%$. 
3. Hasil observasi minat siswa

Data dari hasil observasi siswa pada siklus II dapat diketahui bahwa minat belajar siswa Kelas III SD Negeri 060819 Kec. Medan Kota, dapat dikatakan sudah lebih meningkat. Hal ini dapat dilihat dari data observasi siswa yang berdasarkan dari indikator minat, yaitu:

a. Observasi siswa mengenai minat mengikuti pelajaran terdiri dari 4 deskriptor, yaitu siswa memperhatikan guru mengajar sebanyak 29 siswa (97\%), siswa tidak ribut pada saat pembelajaran berlangsung sebanyak 25 siswa (83\%), siswa menulis pelajaran yang disampaikan guru sebanyak 26 siswa (87\%), siswa mampu mempraktekkan pelajaran sesuai dengan permintaan guru sebanyak 24 siswa (80\%).

b. Observasi siswa mengenai minat pemanfaatan waktu belajar terdiri dari 4 deskriptor, yaitu siswa menyusun kegiatan belajar sehari-hari sebanyak 24 siswa $(80 \%)$, siswa tidak suka berlama -lama di luar kelas pada saat istirahat sudah berakhir sebanyak 26 siswa (87\%), siswa memanfaatkan waktu istirahat untuk mendiskusikan pelajaran dengan temannya sebanyak 23 siswa (77\%), siswa tidak suka bermain sebelum tugasnya selesai sebanyak 27 siswa (90\%)

c. Observasi siswa mengenai minat mengulang pelajaran kembali terdiri dari 4 deskriptor, yaitu siswa membaca buku pelajaran setelah pelajaran berakhir sebanyak 24 siswa (80\%), siswa membuat ringkasan setelah pelajaran berakhir sebanyak 26 siswa (87\%), siswa mengingat apa yang sudah dipelajari sebanyak 28 siswa (93\%), siswa mengerjakan PR sebanyak 30 siswa (100\%).

d. Observasi siswa mengenai minat menyenangi pelajaran terdiri dari 4 deskriptor, yaitu siswa cepat datang ke sekolah sebanyak 29 siswa (97\%), siswa menyediakan perlengkapan untuk belajar sebanyak 30 siswa (100\%), siswa memberi tanda pada hal-hal yang penting sebanyak 24 siswa (80\%), siswa selalu bersemangat pada saat mengikuti pembelajaran sebanyak 22 siswa $(73 \%)$.

e. Observasi siswa mengenai minat aktif di dalam kelas terdiri dari 4 deskriptor, yaitu siswa selalu menuls dan mencatat pelajaran penting sebanyak 27 siswa 
f. (90\%), siswa sering bertanya sebanyak 24 siswa (80\%), siswa sering menjawab pertanyaan sebanyak 24 siswa (80\%), siswa selalu mengeluarkan pendapat dalam diskusi kelompok sebanyak 26 siswa (87\%).

Dari hasil observasi siklus II pada tabel di atas telah mencapai taraf persentase yang cukup tinggi. Hasil observasi siklus II yang dilakukan oleh guru dari 30 jumlah siswa, yakni diperoleh nilai sebagai berikut: Siswa yang berminat sebanyak 20 orang dengan persentase $67 \%$. Dari hasil observasi siswa yang telah dilakukan pada siklus II, maka hasilnya adalah: 1) peneliti sudah menguasai kelas dengan baik, karena peneliti sudah lebih menguasai bahan ajar, 2) siswa sudah aktif dalam menjawab/menyelesaikan tugas yang diberikan peneliti, karena peneliti sudah menguasai model pembelajaran dan menggunakan media gambar, 3) di dalam proses pembelajaran, peneliti sudah dapat menggunakan waktu yang efektif sehingga tujuan pembelajaran tercapai, 4) aktivitas guru dalam bertanya kepada siswa, sudah cukup tinggi, memperhatikan dan membimbing siswa sudah meningkat, karena interaksi antara peneliti dan siswa pada saat proses belajar mengajar berlangsung dengan cukup baik, 5) tahap kegiatan akhir, guru sudah dapat melaksanakan penilaian pembelajaran dan lebih sempurna lagi dalam merangkum isi pelajaran. Peningkatan minat belajar siswa melalui penggunaan model pembelajaran kooperatif tipe tari bambu telah tercapai dengan baik, sehingga tidak perlu lagi dilanjutkan ke siklus berikutnya.

\section{Pembahasan}

Dari hasil pengujian hipotesis, yaitu "Dengan menggunakan model pembelajaran Kooperatif Tipe Tri Bambu dapat meningkatan minat belajar siswa pada mata pelajaran Bahasa Indonesia pokok bahasan menanggapi isi cerita secara lisan di Kelas III SD Negeri 060819 Kec. Medan Kota".

Pada siklus I digunakan pembelajaran Kooperatif tipe Tari Bambu dengan media gambar maka hasil yang di dapat pada siklus I adalah:

a. Siswa yang berminat sebanyak 1 orang dengan persentase $3 \%$.

b. Siswa yang cukup berminat sebanyak 5 orang dengan persentase $17 \%$.

c. Siswa yang kurang berminat sebanyak 24 orang dengan persentase $80 \%$.

Pada siklus II digunakan pembelajaran Kooperatif Tipe Tari Bambu dengan media gambar maka hasil yang di dapat pada siklus II adalah: 
a. Siswa yang sangat berminat sebanyak 20 orang dengan persentase $67 \%$.

b. Siswa yang berminat sebanyak 10 orang dengan persentase $33 \%$

Hal ini berarti dengan menerapkan pembelajaran Kooperatif tipe Tari Bambu dapat meningkatkan minat belajar siswa pada mata pelajaran Bahasa Indonesia pokok bahasan menanggapi isi cerita secara lisan, terlihat dari peningkatan persentase minat siswa yang terjadi. Berikut ini disajikan rata-rata hasil observasi mulai dari siklus I hingga siklus II, sehingga dapat melihat peningkatan minat belajar yang tercapai, dengan menerapkan pembelajaran Kooperatif tipe Tari Bambu.

Tabel 4.10 Peningkatan Nilai RataRata Siswa

\begin{tabular}{|c|c|c|c|}
\hline \multirow{2}{*}{ No. } & \multirow{2}{*}{ Observasi } & \multicolumn{2}{|c|}{ Nilai Rata - Rata } \\
\cline { 3 - 4 } & & Jumlah & $\%$ \\
\hline 1 & Siklus I & 44 & 55 \\
\hline 2 & Siklus II & 69 & 87 \\
\hline
\end{tabular}

\section{SIMPULAN}

1. Dengan menggunakan model pembelajaran kooperatif tipe tari bambu, dapat meningkatkan minat belajar siswa dalam mata pelajaran Bahasa Indonesia pada pokok bahasan menanggapi isi cerita secara lisan di Kelas III SD
Negeri 060819 Kec. Medan Kota Tahun Ajaran 2015/2016.

2. Pada observasi minat belajar siswa siklus I rata-rata nilai keseluruhan yang diperoleh hanya mencapai 44 , persen $(\%)$ yang diperoleh sebesar 55\%. Dari hasil hitungan observasi siswa siklus I masih tergolong rendah. Pada siklus II rata - rata nilai keseluruhan yang diperoleh yaitu sebesar 69, persen (\%) yang diperoleh adalah sebesar $87 \%$. Pada siklus II dapat dilihat bahwa peneliti sudah meningkatkan penggunaan model pembelajaran kooperatif tipe tari bambu dengan baik dan perilaku belajar siswa sudah meningkat.

Berdasarkan hasil penelitian dan kesimpulan yang dikemukakan diatas, maka guru memberi beberapa saran, yaitu:

1. Agar para kepala sekolah melakukan supervisi dengan pembaharuan pembelajaran Bahasa Indonesia serta pendalaman penggunaan model pemebelajaran kooperatif tipe Tari Bambu.

2. Agar para guru SD Negeri 060819 Kec.Medan Kota menerapkan penggunaan model pembellajaran kooperatif tipe Tari Bambu sebagai salah satu alternatif dalam meningkatkan minat belajar siswa. 
3. Agar pihak sekolah SD Negeri 060819 Kec.Medan Kota semakin memaksimalkan penerapan model pembelajaran kooperatif tipe Tari Bambu yang berfokus pada memaksimalkan aktivitas belajar siswa untuk meningkatkan kualitas pembelajaran. Guru dan orang tua saling bekerjasama dalam meningkatkan hasil belajar siswa.

\section{DAFTAR RUJUKAN}

Arikunto, Suharsimi. 2006. Prosedur Penelitian Suatu Pendekatan Praktik. Jakarta: PT. Bumi Aksara.

Bahri, Syaiful, dkk. 2006. Strategi Belajar Mengajar. Jakarta: PT. Rineka Cipta.

Daryanto. 2009. Panduan Proses Pembelajaran Kreatif \& Inovatif. Jakarta: AV Publisher.
Djaali. 2006. Psikologi Pendidikan. Jakarta: PT. Bumi Aksara.

Isjoni. 2009. Pembelajaran Kooperatif. Yogyakarta: Pustaka Pelajar.

Lie, Anita. 2010. Cooperative Learning. Jakarta: GRASINDO.

Muslich, M. 2011. Melaksanakan PTK itu mudah. Malang: BUMI AKSARA.

Sanjaya, Wina. 2008. Strategi Pembelajaran. Bandung: Kencana.

Syah, Muhibbin. 2010. Psikologi Pendidikan. Bandung: Remaja Rosdakarya.

Slameto. 2010. Belajar dan Faktor faktor yang Mempengaruhinya. Jakarta: PT. Rineka Cipta.

Suyatno. 2010. Teknik Pembelajaran Bahasa dan Sastra. Surabaya: SIC 